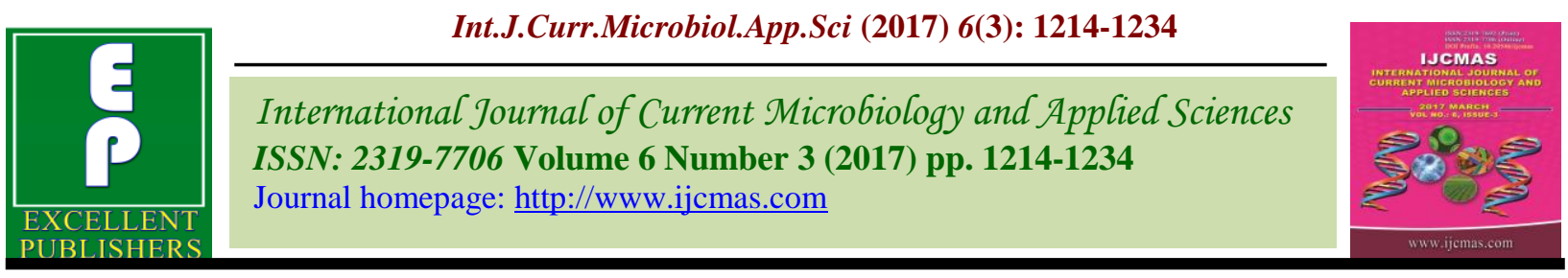

Original Research Article

https://doi.org/10.20546/ijcmas.2017.603.141

\title{
Meta-analysis of Prevalence of Subclinical and Clinical Mastitis, Major Mastitis Pathogens in Dairy Cattle in India
}

\author{
P. Krishnamoorthy*, K.P. Suresh, S. Saha, G. Govindaraj, B.R. Shome and Parimal Roy \\ ICAR- National Institute of Veterinary Epidemiology and Disease Informatics (NIVEDI), \\ Post Box No.6450, Ramagondanahalli, Yelahanka, Bengaluru 560064, India \\ *Corresponding author
}

\begin{tabular}{|c|c|}
\hline & A B S T R A C T \\
\hline & In the present study, pooled prevalence of subclinical mastitis [SCM], clinical mastitis \\
\hline Keywords & and Escherichia coli in dairy animals was studied by using meta-analysis. Based on \\
\hline $\begin{array}{l}\text { Meta-analysis, } \\
\text { Prevalence, } \\
\text { Subclinical, Clinical } \\
\text { mastitis, India. }\end{array}$ & $\begin{array}{l}\text { systematic review of studies on mastitis from } 2005-2016 \text { using online and offline } \\
\text { databases, meta-analysis was done. Meta-analysis of } 43 \text { and } 22 \text { studies on SCM and CM, } \\
\text { respectively was carried out with random effects model using Metaprop package in R- } \\
\text { Software. The pooled prevalence of SCM and CM were } 41 \% \text { [33-49\%] and } 27 \% \text { [19- }\end{array}$ \\
\hline Article Info & $\begin{array}{l}37 \% \text { ], obtained by using } 25,455 \text { and } 6,978 \text { dairy animals. Pooled prevalence estimate of } \\
\text { Staphylococcus sp., Streptococcus sp. and Escherichia coli were } 45 \%, 13 \% \text { and } 14 \% \text {, }\end{array}$ \\
\hline $\begin{array}{l}\text { Accepted: } \\
\text { 20 February } 2017 \\
\text { Available Online: } \\
10 \text { March } 2017\end{array}$ & $\begin{array}{l}\text { respectively. Period-wise analysis revealed prevalence of SCM, Staphylococcus sp., } \\
\text { increased and CM, E. coli prevalence decreased indicating the importance of SCM and } \\
\text { Staphylococcus species in mastitis. Zone-wise estimates for SCM and CM were high in } \\
\text { South and North zone, respectively. The prevalence of subclinical and Staphylococcus }\end{array}$ \\
\hline & $\begin{array}{l}\text { species mastitis was high, which may cause low productivity in dairy cattle and economic } \\
\text { loss to dairy farmers. Hence, there is a need to reduce the prevalence of subclinical and } \\
\text { clinical mastitis by adopting scientific management, feeding and therapeutic measures for } \\
\text { better economy of the dairy farmers. }\end{array}$ \\
\hline
\end{tabular}

\section{Introduction}

Mastitis is an economically important disease of dairy animals and causes economic loss to dairy farmers in India. It is the most expensive disease of dairy cattle resulting in the reduction in milk production, losses in milk quality and quantity, losses due to discarded milk, premature culling, treatment costs and labour cost (Hogeveen et al., 2011). The severity of the inflammation can be classified into sub-clinical, clinical and chronic forms, and its degree is dependent on the nature of the causative pathogen and on the age, breed, immunological health and lactation state of the animal. Sub-clinical mastitis is difficult to be detected due to the absence of any visible indications, and it has major cost implications. Clinical mastitis is a condition in which swelling of the udder and flakes in milk are common signs. Chronic mastitis is a rare form of the disease but results in persistent inflammation of the mammary gland. In India, the total annual economic losses due to mastitis was calculated to be 7165.51 crore rupees (Bansal and Gupta, 2009). 
Previous studies on prevalence of subclinical and clinical mastitis conducted in different states of India have reported to be high is some studies and low in another. The prevalence of mastitis in dairy animals was found to be variable from study to study due to the variations in the period and location of study, breed of animal, stage of lactation, number of samples tested, sampling strategies and management practices of the dairy farms. Previous literature has reported the metaanalysis of prevalence of subclinical mastitis in dairy cows for the period 1995-2014 (Bangar et al., 2015), however, the metaanalysis of prevalence of clinical mastitis and major mastitis pathogens were not reported so far. Among the bacteria isolated in bovine mastitis, Staphylococcus species occupies an important place. Till date, more than 50 Staphylococcal species and subspecies have been characterized. The prevalence of the major mastitis pathogens in India like Staphylococcus sp., Streptococcus sp. and Escherichia coli are also variable in milk of dairy animals. It is pertinent to collect the information on the prevalence of subclinical and clinical mastitis and major mastitis pathogens across different states of India, which may act as baseline information for devising mastitis control strategies and will be useful to reduce the economic losses due to mastitis in dairy sector. Hence, the present study was undertaken to do meta-analysis of available literatures on prevalence of mastitis in India to obtain the pooled and efficient estimates for subclinical and clinical mastitis, and major mastitis pathogen prevalence among dairy animals in India during the period 2005-2016.

\section{Materials and Methods}

\section{Search strategy}

Systematic research was performed on the literature about prevalence of subclinical and clinical mastitis in dairy animals in India. The databases included were Pubmed, Springer, Elsevier, Indian journals.com, Consortium of e-Resources in Agriculture (CeRA) under Indian Council of Agricultural Research, conference, seminar and symposium abstracts, etc. The studies addressing the SCM, CM and major mastitis pathogens viz., Staphylococcus sp., Streptococcus sp., and E. coli were collected for the meta-analysis. More than 100 articles were searched and results were subjected to meta-analysis to determine the prevalence rate with respect to various periods and states in India. The articles from study area based on the states in India was divided into five zones viz., North, East, West, South and Central zones. The literature search from different publications was undertaken the period from 2005 to 2016 for subclinical, clinical mastitis and major mastitis pathogen prevalence. Given a vast quantity of literature, the type of items that were collected includes the characteristics of the publications (author, year, country, state, no of samples tested and prevalence rate in different livestock species such as cattle and buffalo). The retrieval dates were limited to the period from January 2005 to August 2016 and the retrieval language was limited to English. Finally, the original articles, review articles and references cited from the retrieved articles were searched.

\section{Data entry and filtration}

Two reviewers independently extracted the characteristics of each included study onto predesigned Excel forms. These included publication year, authors, study participant eligibility criteria, study period, numbers of animals positive for mastitis, the total number of animals tested and the test used. The test used for diagnosis of prevalence of SCM and $\mathrm{CM}$ was California mastitis test and for major mastitis pathogens was isolation and identification by molecular methods by PCR. 
Results from the previous research found in the literature must be entered in a database. The coding of the database was done with numerous variables identifying the experimental objectives of all the experiments selected. Hence, numerous columns are potentially added to code each objective found in all the sources of experimental data. This coding is necessary so as to avoid the improper aggregation of results across the studies with very different objectives. During the coding, we have chosen to transform the continuous variable to discrete variable with $n$ levels coded in a single column with levels of discrete variables as entries. Different criteria can guide the selection of classes, such as equidistant classes, classes with equal frequencies or probability of occurrence. The important point was that sum of these descriptive columns must entirely characterize the objective of all studies used. There were at least three steps necessary to effective data filtering. First, the analyst must ensure that the study under consideration was coherent with the objectives of the metaanalysis. The meta-analysis objectives dictate that some traits must be measured and reported. The second step consisted of a thorough and critical review of each publication under consideration, focusing on the detection of errors in the reporting of the quantitative results. Verification of data entries was essential component to this process. In the third step, it was important to ensure that a selected publication does not appear to be an outlier with respect to the characteristics and relations under considerations.

\section{Meta-analysis}

In the most general terms, meta-analysis was one method of research synthesis. It employs specialized techniques for data gathering and analysis developed specifically for the purposes of research synthesis (Koricheva et al., 2013). Using a rigorous systematic protocol, systematic reviews was used to synthesize findings from available research reports is the gold standard for measuring the effectiveness of preventive and therapeutic interventions for the specified conditions. The overall effect calculated from a group of sensibly combined and representative condition or criteria provides an essentially unbiased estimate of the effect, with an increase in the precision of this estimate.

\section{Test of significance of homogeneity}

The test for equality of $\mathrm{k}$ variances was carried used in this study. The $\mathrm{k}$ studyspecific summary statistics shared a common mean $\theta$. A statistical test for the homogeneity of study means was equivalent to testing,

$\mathrm{H}_{0}: \theta=\theta_{1}=\theta_{2}=\ldots \ldots \theta_{\mathrm{k}} \quad$ against

$\mathrm{H}_{1}$ : At least one ${ }^{\theta_{\mathrm{i}}}$ is different. Under $\mathrm{H}_{0}$, for large sample sizes,

$\mathrm{Q}_{\mathrm{w}}=\sum_{1}^{k} w_{i}\left(\mathrm{y}_{\mathrm{i}}-\theta_{\mathrm{MLE}}\right) \quad$ Follows Chi-square with (k-1) degrees of freedom

Where, $\hat{\theta_{\mathrm{MLE}}}=\frac{\sum \mathrm{w}_{\mathrm{i}} \mathrm{y}_{\mathrm{i}}}{\sum \mathrm{w}_{\mathrm{i}}}$ and $\mathrm{w}_{\mathrm{i}}=\frac{1}{\mathrm{~s}_{\mathrm{i}}^{2}}$

After testing for the significance of heterogeneity of studies based on chi-square test and $\mathrm{Tau}^{2}$, depending upon the $\mathrm{Tau}^{2}$ (heterogeneity coefficient), fixed effect and random effect models were selected for integrating the results. When the $\mathrm{Tau}^{2}$ value is zero, the Inverse variance method was used as fixed effect model, otherwise a random effect model by Der Simonian and Laird Method (Koricheva et al., 2013). The random effect model allows the study variation to some extent while integrating the results. 
Inverse-Variance Method (Fixed Effect model): The Inverse-Variance Method (IV method) was used for pooling either binary, continuous or correlation data. This approach was used, which has wide applicability since it can be used to combine any estimate that has standard error available. The effect size or mean are combined to give a pooled estimate (denoted by $\theta$ ) by calculating weighted average of the treatment effects from the individual studies as follows.

$\theta_{\mathrm{IV}}=\frac{\sum \mathrm{w}_{\mathrm{i}} \theta_{\mathrm{i}}}{\sum \mathrm{w}_{\mathrm{i}}}$

Where the weights $\mathrm{w}_{\mathrm{i}}$ are calculated as, $\mathrm{w}_{\mathrm{i}}=\frac{1}{\mathrm{SE}\left(\theta_{\mathrm{i}}\right)^{2}}$

That is, the weight for the $\mathrm{i}^{\text {th }}$ study is equal to its precision of the estimate.

The standard error of $\theta_{\mathrm{IV}}$ is given by $\operatorname{SE}\left(\theta_{\mathrm{IV}}\right)=\frac{1}{\sqrt{\sum \mathrm{w}_{\mathrm{i}}}}$

The heterogeneity statistic (denoted by $Q_{w}$ ) is given by,

$$
\mathrm{Q}_{\mathrm{w}}=\sum \mathrm{w}_{\mathrm{i}}\left(\theta_{\mathrm{i}}-\theta_{\mathrm{IV}}\right)^{2}
$$

The $Q_{w}$ follows chi-square distribution with ( $\mathrm{k}-1)$ degrees of freedom, where $\mathrm{k}$ is the number of studies included in the metaanalysis.

DerSimonian and Laird Method (Random Effect Model): The DerSimonian and Laird method (DL method) of meta-analysis is based on the random effects model. Under the random effects model, the assumption of common effect is relaxed, and the effect size or mean $\theta_{\mathrm{i}}$ are assumed to have a normal distribution with mean $\theta$ and variance $\tau^{2}$. The usual DL estimate for $\tau^{2}$ is given by,

$$
\tau^{2}=\frac{\mathrm{Q}_{\mathrm{w}}-(\mathrm{k}-1)}{\sum \mathrm{w}_{\mathrm{i}}-\frac{\sum \mathrm{w}_{\mathrm{i}}^{2}}{\sum \mathrm{w}_{\mathrm{i}}}}
$$

Where $\mathrm{Q}_{\mathrm{w}}$ is the heterogeneity statistic, and the weights $\mathrm{w}_{\mathrm{i}}$ are calculated as in the IV Method, and $\mathrm{k}$ is the number of studies. The $\tau^{2}$ is set to zero if $\mathrm{Q}_{\mathrm{w}}<(\mathrm{k}-1)$. In this approach, the weights for each study effect size $\mathrm{w}_{\mathrm{i}}^{\prime}$ are as given below.

$\mathrm{w}_{\mathrm{i}}^{\prime}=\frac{1}{\operatorname{SE}\left(\theta_{\mathrm{i}}\right)^{2}+\tau^{2}}$

The pooled estimate is given by,

$\theta_{\mathrm{DL}}=\frac{\sum \mathrm{w}_{\mathrm{i}}^{\prime} \theta_{\mathrm{i}}}{\sum \mathrm{w}_{\mathrm{i}}^{\prime}}$

With standard error,

$\operatorname{SE}\left(\theta_{\mathrm{DL}}\right)=\frac{1}{\sqrt{\sum \mathrm{w}_{\mathrm{i}}^{\prime}}}$

The heterogeneity statistic and its test of significance are as given in the IV method.

\section{Forest plots}

Graphical representation of meta-analysis was done using forest plots. The forest plots are known as confidence interval plots, which displays effect estimates and their confidence intervals for each study and odds ratios (or $\log$ odds ratios), standardized mean differences (effect sizes), correlations (transformations), proportions (transformations), risk ratios (or log risk 
ratios) and differences in means. It includes the result of the overall effect from a metaanalysis, normally at the bottom of the graph, and often using a diamond to distinguish it from the individual studies (Higgins et al., 2013). Meta-analysis was done by using "Metaprop" package of $\mathrm{R}$ 3.1.0 software (Comprehensive R Archive Network). The Q statistics were also calculated using the formula as given below.

$$
\mathrm{Q}=\frac{(1-\mathrm{K})}{\left(\mathrm{I}^{2}-1\right)}
$$

Where, K-Number of studies, I ${ }^{2}$ - I squared value.

The Forest plots were prepared for the subclinical and clinical mastitis, and major mastitis pathogens based on total studies, year wise [2005-10 and 2011-16] and five zones separately. The prevalence estimates for subclinical, clinical and major pathogens in mastitis was expressed as percentage and also with confidence interval [CI] at $95 \%$ level.

\section{Results and Discussion}

\section{Details of prevalence studies}

The present study was carried out based on systematic review of prevalence of subclinical, clinical, Staphylococcus sp., Streptococcus sp. and E. coli mastitis in dairy animals of India for the period 2005-2016. The details of the studies on mastitis with location, zones and prevalence studied are presented in table 1 . The forest plot analysis was carried out to show the meta-analysis results for better understanding and to determine the heterogeneity between the various studies. The prevalence studies included in this study were from nineteen states in India which includes Andhra Pradesh, Arunachal Pradesh, Bihar,
Chhattisgarh, Gujarat, Haryana, Jammu and Kashmir, Jharkhand, Karnataka, Kerala, Madhya Pradesh, Maharashtra, Odisha, Punjab, Rajasthan, Sikkim, Tamil Nadu, Uttarakhand and Uttar Pradesh. The highest number of studies on mastitis prevalence was reported from Karnataka [10] followed by other states in India. The number of studies across different zones reported was 27, 7, 12, 24 and 2 from North, East, West, South and Central zones, respectively. There were fewer studies on mastitis from East and Central zones compared to other zones.

\section{Meta-analysis of subclinical and clinical mastitis}

The detailed results of meta-analysis of prevalence studies of subclinical and clinical mastitis in India are presented in table 1. The Forest plot for subclinical and clinical mastitis is depicted in figures 1 and 2 . The number of studies on subclinical and clinical mastitis were 43 and 22, respectively was studied with a total of 25,455 and 6,978 samples from dairy animals for testing for subclinical and clinical mastitis, respectively. The pooled estimates for prevalence of subclinical and clinical mastitis were $41 \%$ (95\% CI 33-49\%) and $27 \%$ (95\% CI 19-37\%), respectively.

The subclinical mastitis showed increased prevalence from 29 to $45 \%$ during 2011-16 period compared to the clinical mastitis. This endorses the importance of subclinical mastitis than the clinical mastitis over the years. The zone wise analysis revealed increased prevalence of subclinical mastitis in East zone $(50 \%)$ and clinical mastitis in North zone $(35 \%)$. The clinical mastitis studies were limited or no studies from East and Central zones in India. The Q statistics for SCM and $\mathrm{CM}$ showed highly significant $(\mathrm{P}<0.0001)$ difference between the studies and are depicted in table 2. This indicated there was significant heterogeneity between the various 
studies on SCM and CM prevalence reports from various states in India.

\section{Meta-analysis of major mastitis pathogens}

The results of meta-analysis of prevalence studies of major mastitis pathogens viz., Staphylococcus sp., Streptococcus sp. and Escherichia coli are presented in table 1 and 2. The Forest plots for major mastitis pathogens are depicted in figures 3, 4 and 5 . The number of studies on prevalence of Staphylococcus sp., Streptococcus sp. and Escherichia coli were 45, 40 and 39 with the overall samples studied were 9856, 13058 and 13315, respectively. Pooled estimate of prevalence of Staphylococcus sp., Streptococcus sp. and Escherichia coli were 45, 13 and 14\%, respectively. The periodwise analysis showed increased prevalence for Staphylococcus sp., whereas it showed decreasing trend for E. coli during 2011-16. However, there was more or less same trend over the years for prevalence of Streptococcus species from dairy animals. The zone wise analysis showed high prevalence of Staphylococcus sp., Streptococcus sp. in North zone and Escherichia coli in West zones, respectively. The $\mathrm{Q}$ statistics revealed highly significant difference, indicating the heterogeneity between the studies for major mastitis pathogen prevalence in dairy cows. However, there was no significant difference for Streptococcus sp. prevalence during 2005 10, and Staphylococcus species, Streptococcus species and E. coli in Central zone, which indicated homogeneity between the prevalence studies.

The results of meta-analysis provides a quantitative level of mastitis prevalence by considering differences in the results and approaches followed by various researchers in different studies from various states of India. A substantial benefit of meta-analysis is the potential to investigate the new hypothesis using existing data, both through the development of a priori hypothesis and by examination of heterogeneity. The dairy animals are affected by mastitis and causes great economic loss to dairy farmers despite adopting many preventive measures for SCM and $\mathrm{CM}$ in dairy cows. The present study revealed the pattern of prevalence of subclinical, clinical and major mastitis pathogens in mastitis in dairy animals from various organized and unorganized farms over the period of twelve years from different parts of the India. This study showed that the SCM was increasing and CM prevalence was decreasing over the past six year period [2011-16]. Further, there was high heterogeneity was observed between various studies for the estimates of mastitis prevalence and it might be due to various factors like parity of cattle, lactation stage and genetic makeup of animals, agroclimatic conditions and farm managemental practices (Joshi and Gokhale, 2006). More number of studies on SCM (32) and CM (19) prevalence are being reported during 2011-16 indicating the importance of mastitis in dairy cows in India during recent years.

In the present study, prevalence of subclinical mastitis at cow level was $41 \%$ and was slightly less when compared to previous meta-analysis study on subclinical mastitis was $46.35 \%$ in cows (Bangar et al., 2015). However, the past study reported the prevalence of subclinical mastitis ranges from 15 to $75 \%$ (Cynthia, 2005) and concurred with the present study. The estimated prevalence observed in the present study was in agreement with results reported earlier for Bangladesh (Rahman et al., 2010) and Sri Lanka (Samarakoon et al., 2014). However, less prevalence was reported as $29.5 \%$ (Islam et al., 2011) and $20.2 \%$ (Sarker et al., 2013) in Bangladesh for SCM. The pooled estimates of $\mathrm{CM}$ prevalence were $27 \%$, which was less when compared to the SCM, indicating the importance of SCM in India. 
Table.1 Details of the mastitis studies included in systematic review and meta-analysis

\begin{tabular}{|c|c|c|c|c|}
\hline No. & Study [Author and year] & Study locations in India & Zones & $\begin{array}{c}\text { Prevalence } \\
{[\mathrm{SCM}=1, \mathrm{CM}=2, \mathrm{MMP}} \\
=3]\end{array}$ \\
\hline 1. & Sudhan et al., 2005 & Jammu and Kashmir & North & 1,3 \\
\hline 2. & Bulla et al., 2006 & Haryana & North & 1,3 \\
\hline 3. & Sharma N et al., 2007 & $\begin{array}{l}\text { Chhattisgarh and Madhya } \\
\text { Pradesh }\end{array}$ & Central & 1,3 \\
\hline 4. & Sharma A et al., 2007 & Haryana & North & $1,2,3$ \\
\hline 5. & Sumathi et al., 2008 & Karnataka & South & 3 \\
\hline 6. & De and Reena, 2009 & Uttar Pradesh & North & $1,2,3$ \\
\hline 7. & Kavitha et al., 2009 & Andhra Pradesh & South & 1 \\
\hline 8. & Sindhu et al., 2009 & Haryana & North & 1 \\
\hline 9. & Sudhakar et al., 2009 & Maharashtra & West & 3 \\
\hline 10. & Bhikane et al., 2010 & Maharashtra & West & 3 \\
\hline 11. & Dubal et al., 2010 & Sikkim & East & $1,2,3$ \\
\hline 12. & Elango et al., 2010 & Tamil Nadu & South & 1,3 \\
\hline 13. & Sharma et al., 2010 & Rajasthan & West & 1,3 \\
\hline 14. & Stanikzai et al., 2011 & Karnataka & South & 1 \\
\hline 15. & Bhatt et al., 2011 & Gujarat & West & 1,2 \\
\hline 16. & Guha et al., 2011 & Haryana & North & 1,3 \\
\hline 17. & Harini and Sumathi, 2011 & Karnataka & South & 1,3 \\
\hline 18. & Ranjan et al., 2011 & Jharkhand & East & 3 \\
\hline 19. & Bhandari and Garg, 2012 & Punjab & North & 1 \\
\hline 20. & Bhanot et al., 2012 & Haryana & North & 3 \\
\hline 21. & Mubarack et al., 2012 & Tamil Nadu & South & $1,2,3$ \\
\hline 22. & Patel et al., 2012 & Gujarat & West & 1,3 \\
\hline 23. & Sadashiv and Kaliwal, 2012 & Karnataka & South & 3 \\
\hline 24. & Sharma et al., 2012 & Punjab & North & 1 \\
\hline 25. & Sharma A et al., 2012 & Jammu and Kashmir & North & 1 \\
\hline 26. & Sukumar and James, 2012 & Kerala & South & 2 \\
\hline 27. & Sundareshan et al., 2012 & $\begin{array}{l}\text { Hyderabad, Andhra } \\
\text { Pradesh }\end{array}$ & South & 3 \\
\hline 28. & Tufani et al., 2012 & Jammu and Kashmir & North & 2,3 \\
\hline 29. & Visvanath et al., 2012 & Tamil Nadu & South & $1,2,3$ \\
\hline 30. & Ayyappadas et al., 2013 & Tamil Nadu & South & 3 \\
\hline 31. & Bajjaragi et al., 2013 & Karnataka & South & 3 \\
\hline 32. & Hegde et al., 2013 & Karnataka & South & 1,3 \\
\hline 33. & Hussain et al., 2013 & Jammu and Kashmir & North & 2,3 \\
\hline 34. & Jeyakumar et al., 2013 & Tamil Nadu & South & 3 \\
\hline 35. & Karabasanavar et al., 2013 & Uttarakhand & North & 3 \\
\hline 36. & Mohanty et al., 2013 & Odisha & East & 3 \\
\hline 37. & Pachauri et al., 2013 & Uttar Pradesh & North & 1,2 \\
\hline 38. & Prakash et al., 2013 & Uttar Pradesh & North & 1,2 \\
\hline
\end{tabular}




\begin{tabular}{|c|c|c|c|c|}
\hline 39. & Singh et al., 2013 & Uttar Pradesh & North & 1,2 \\
\hline 40. & Srinivasan et al., 2013 & Tamil Nadu & South & 1,3 \\
\hline 41. & Thakor et al., 2013 & Gujarat & West & 1 \\
\hline 42. & Biswas et al., 2014 & Arunachal Pradesh & East & 3 \\
\hline 43. & Chougule et al., 2014 & Maharashtra & West & $1,2,3$ \\
\hline 44. & Dar et al., 2014 & Jammu and Kashmir & North & 1 \\
\hline 45. & Kathiriya et al., 2014 & Gujarat & West & 1 \\
\hline 46. & Krishnaveni et al., 2014 & Karnataka & South & $1,2,3$ \\
\hline 47. & Kurjogi et al., 2014 & Karnataka & South & 1,2 \\
\hline 48. & Langer et al., 2014 & Gujarat & West & 1,3 \\
\hline 49. & Mir et al., 2014 & Punjab & North & 1,3 \\
\hline 50. & Patnaik et al., 2014 & Jharkhand & East & 1,3 \\
\hline 51. & Sahu et al., 2014 & Uttar Pradesh & North & 3 \\
\hline 52. & Sarkar et al., 2014 & Haryana & North & 3 \\
\hline 53. & Ali et al., 2015 & Uttar Pradesh & North & 3 \\
\hline 54. & Bhagat et al., 2015 & Gujarat & West & 3 \\
\hline 55. & Bharathy et al., 2015 & Tamil Nadu & South & 3 \\
\hline 56. & Chandrasekaran et al., 2015 & Tamil Nadu & South & 3 \\
\hline 57. & Ganai et al., 2015 & Jammu and Kashmir & North & 2 \\
\hline 58. & Gupta et al., 2015 & Rajasthan & West & 2,3 \\
\hline 59. & Jena et al., 2015 & Rajasthan & West & 1,3 \\
\hline 60. & Kaur A et al., 2015 & Punjab & North & 1,3 \\
\hline 61. & Kaur M et al., 2015 & Punjab & North & 3 \\
\hline 62. & Kumar et al., 2015 & Jharkhand & East & 3 \\
\hline 63. & Kutar et al., 2015 & Uttar Pradesh & North & $1,2,3$ \\
\hline 64. & Prabhu et al., 2015 & Karnataka & South & $1,2,3$ \\
\hline 65. & Sharma et al., 2015 & Uttar Pradesh & North & 3 \\
\hline 66. & $\begin{array}{l}\text { Sudhanthiramani et al., } \\
2015\end{array}$ & Andhra Pradesh & South & 3 \\
\hline 67. & Hardenberg et al., 2016 & Bihar & East & $1,2,3$ \\
\hline 68. & Jagadeesh et al., 2016 & Karnataka & South & 1 \\
\hline 69. & Laxmi et al., 2016 & Kerala & South & 3 \\
\hline 70. & Monica et al., 2016 & Tamil Nadu & South & 3 \\
\hline 71. & Panchal et al., 2016 & Haryana & North & 1,2 \\
\hline 72. & Singh et al., 2016 & Madhya Pradesh & Central & 2,3 \\
\hline
\end{tabular}

Note: SCM-Subclinical mastitis; CM-Clinical mastitis; MMP-Major mastitis pathogens 
Table.2 Meta-analysis of prevalence studies on subclinical mastitis (SCM), clinical mastitis (CM), Staphylococcus sp., Streptococcus sp., and Escherichia coli mastitis in India

\begin{tabular}{|c|c|c|c|c|c|c|c|c|c|}
\hline No. & Parameters & Period & $\begin{array}{l}\text { Number } \\
\text { of } \\
\text { studies }\end{array}$ & $\begin{array}{c}\text { Total } \\
\text { events }\end{array}$ & $\begin{array}{l}\text { Pooled Prevalence } \\
\text { Estimates [\%] } \\
\text { (Confidence interval } \\
\text { at 95\% level) }\end{array}$ & $\begin{array}{l}\text { I- squared } \\
\text { value } \\
(\%)\end{array}$ & $\begin{array}{c}\text { Tau-squared } \\
\text { value }\end{array}$ & $\begin{array}{l}\text { Degrees of } \\
\text { Freedom }\end{array}$ & Q statistics \\
\hline 1 & SCM & $2005-16$ & 43 & 25,455 & $41(33-49)$ & 98.0 & 1.127 & 42 & $2100.0^{* * *}$ \\
\hline 2 & $\mathrm{CM}$ & $2005-16$ & 22 & 6,978 & $27(19-37)$ & 98.5 & 1.159 & 21 & $1400.0^{* * * *}$ \\
\hline 3 & Staphylococcus Species & $2005-16$ & 45 & 9,856 & $45(39-50)$ & 94.1 & 0.59 & 44 & $745.8^{* * * * * *}$ \\
\hline 4 & Streptococcus Species & $2005-16$ & 40 & 13,058 & $13(11-16)$ & 92.4 & 0.497 & 39 & $513.1^{* * * *}$ \\
\hline 5 & Escherichia coli & $2005-16$ & 39 & 13,315 & $14(11-17)$ & 95.3 & 0.7167 & 38 & $808.5^{* * * *}$ \\
\hline \multicolumn{10}{|c|}{ Period wise } \\
\hline 6 & SCM & $2005-10$ & 11 & 7,581 & $29(20-41)$ & 98.3 & 0.6917 & 10 & $588.2^{* * * *}$ \\
\hline 7 & SCM & 2011-16 & 32 & 17,874 & $45(36-55)$ & 97.6 & 1.176 & 31 & $1291.7^{* * * *}$ \\
\hline 8 & $\mathrm{CM}$ & $2005-10$ & 3 & 3,409 & $31(9-66)$ & 99.3 & 1.667 & 2 & $285.7^{* * * *}$ \\
\hline 9 & $\mathrm{CM}$ & 2011-16 & 19 & 3,569 & $26(18-37)$ & 97.2 & 1.161 & 18 & $642.8^{* * * * *}$ \\
\hline 10 & Staphylococcus Sp. & $2005-10$ & 9 & 788 & $39(30-50)$ & 86.6 & 0.3589 & 8 & $59.7^{* * *}$ \\
\hline 11 & Staphylococcus Sp. & $2011-16$ & 36 & 9,068 & $46(39-53)$ & 94.9 & 0.6522 & 35 & $686.2^{* * *}$ \\
\hline 12 & Streptococcus Sp. & $2005-10$ & 8 & 4,185 & $12(11-13)$ & 30.3 & 0.0001 & 7 & $10.0^{\mathrm{ns}}$ \\
\hline 13 & Streptococcus $S p$. & 2011-16 & 32 & 8,873 & $13(10-17)$ & 91.4 & 0.598 & 31 & $360.4^{* * * *}$ \\
\hline 14 & Escherichia coli & $2005-10$ & 9 & 4,279 & $15(9-25)$ & 96.5 & 0.7772 & 8 & $228.5^{* * *}$ \\
\hline 15 & Escherichia coli & 2011-16 & 30 & 9,036 & $13(10-17)$ & 93.7 & 0.7183 & 29 & $460.3^{* * * *}$ \\
\hline \multicolumn{10}{|c|}{ Zone wise } \\
\hline 16 & SCM - North zone & $2005-16$ & 20 & 7,621 & $39(30-49)$ & 97.0 & 0.8141 & 19 & $633.3^{* * * * *}$ \\
\hline 17 & SCM - East zone & $2005-16$ & 3 & 384 & $50(15-85)$ & 97.0 & 2.25 & 2 & $66.7^{* * * *}$ \\
\hline 18 & SCM- West zone & $2005-16$ & 7 & 12,263 & $37(16-64)$ & 98.8 & 2.224 & 6 & $500.0^{* * * *}$ \\
\hline 19 & SCM - South zone & $2005-16$ & 12 & 3,187 & $47(33-61)$ & 96.8 & 1.004 & 11 & $343.7^{* * * *}$ \\
\hline 20 & SCM - Central zone & $2005-16$ & 1 & - & - & - & - & - & - \\
\hline 21 & CM - North zone & $2005-16$ & 11 & 4,988 & $35(23-50)$ & 98.6 & 0.9795 & 10 & $714.2^{* * * * *}$ \\
\hline 22 & CM - East zone & $2005-16$ & 1 & - & - & - & - & - & - \\
\hline 23 & CM- West zone & $2005-16$ & 3 & 480 & $19(4-56)$ & 97.1 & 2.118 & 3 & $68.9^{* * * *}$ \\
\hline
\end{tabular}




\begin{tabular}{|c|c|c|c|c|c|c|c|c|c|}
\hline 24 & CM - South zone & $2005-16$ & 6 & 1,090 & $20(6-34)$ & 97.3 & 1.285 & 5 & $185.1^{* * * *}$ \\
\hline 25 & CM - Central zone & $2005-16$ & No data & - & - & - & - & - & - \\
\hline 26 & Staphylococcus Sp.-North zone & $2005-16$ & 16 & 6,422 & $47(35-52)$ & 96.5 & 0.7539 & 15 & $428.5^{\text {***: }}$ \\
\hline 27 & Staphylococcus Sp.-East zone & $2005-16$ & 6 & 651 & $38(27-50)$ & 87.3 & 0.3486 & 5 & $39.3^{* * *}$ \\
\hline 28 & Staphylococcus Sp.-West zone & $2005-16$ & 6 & 577 & $43(22-67)$ & 88.4 & 1.382 & 5 & $43.1^{* * * *}$ \\
\hline 29 & Staphylococcus Sp.-South zone & $2005-16$ & 15 & 2,072 & $45(36-54)$ & 93.3 & 0.4812 & 14 & $208.9^{* * * *}$ \\
\hline 30 & Staphylococcus Sp.-Central zone & $2005-16$ & 2 & 134 & $52(43-60)$ & 10.5 & 0.0123 & 1 & $1.1^{\mathrm{ns}}$ \\
\hline 31 & Streptococcus Sp.-North zone & $2005-16$ & 14 & 9,914 & $15(10-20)$ & 95.9 & 0.4258 & 13 & $317.1^{\text {***: }}$ \\
\hline 32 & Streptococcus Sp.-East zone & $2005-16$ & 7 & 796 & $8(4-17)$ & 91.5 & 1.018 & 6 & $70.5^{* * * *}$ \\
\hline 33 & Streptococcus Sp.-West zone & $2005-16$ & 5 & 505 & $13(7-22)$ & 69.5 & 0.3707 & 4 & $13.1^{*}$ \\
\hline 34 & Streptococcus Sp.-South zone & $2005-16$ & 12 & 1,709 & $13(9-19)$ & 89.9 & 0.4782 & 11 & $108.9^{\text {****is }}$ \\
\hline 35 & Streptococcus Sp.-Central zone & $2005-16$ & 2 & 134 & $20(10-36)$ & 58.9 & 0.1941 & 1 & $2.4^{\mathrm{ns}}$ \\
\hline 36 & Escherichia coli-North zone & $2005-16$ & 10 & 9,276 & $8(5-13)$ & 97.7 & 0.6697 & 9 & $391.3^{\text {***: }}$ \\
\hline 37 & Escherichia coli-East zone & $2005-16$ & 6 & 651 & $15(10-21)$ & 68.3 & 0.1761 & 5 & $15.7^{* *}$ \\
\hline 38 & Escherichia coli-West zone & $2005-16$ & 7 & 707 & $19(9-34)$ & 89.9 & 1.074 & 6 & $59.4^{* * * * *}$ \\
\hline 39 & Escherichia coli-South zone & $2005-16$ & 14 & 2,547 & $15(10-23)$ & 93.3 & 0.7098 & 13 & $194.0^{* * * * 1}$ \\
\hline 40 & Escherichia coli-Central zone & $2005-16$ & 2 & 134 & $13(9-20)$ & 0.0 & 0.0 & 1 & $1.0^{\mathrm{ns}}$ \\
\hline
\end{tabular}

Note: ns- Non Significant; *- Significant at $\mathrm{P}<0.05 ; * *$ - Significant at $\mathrm{P}<0.01$; *** Significant at $\mathrm{P}<0.001$ 
Fig.1 Forest plot showing the prevalence of subclinical mastitis reported by various studies and events indicates number of mastitis affected bovines

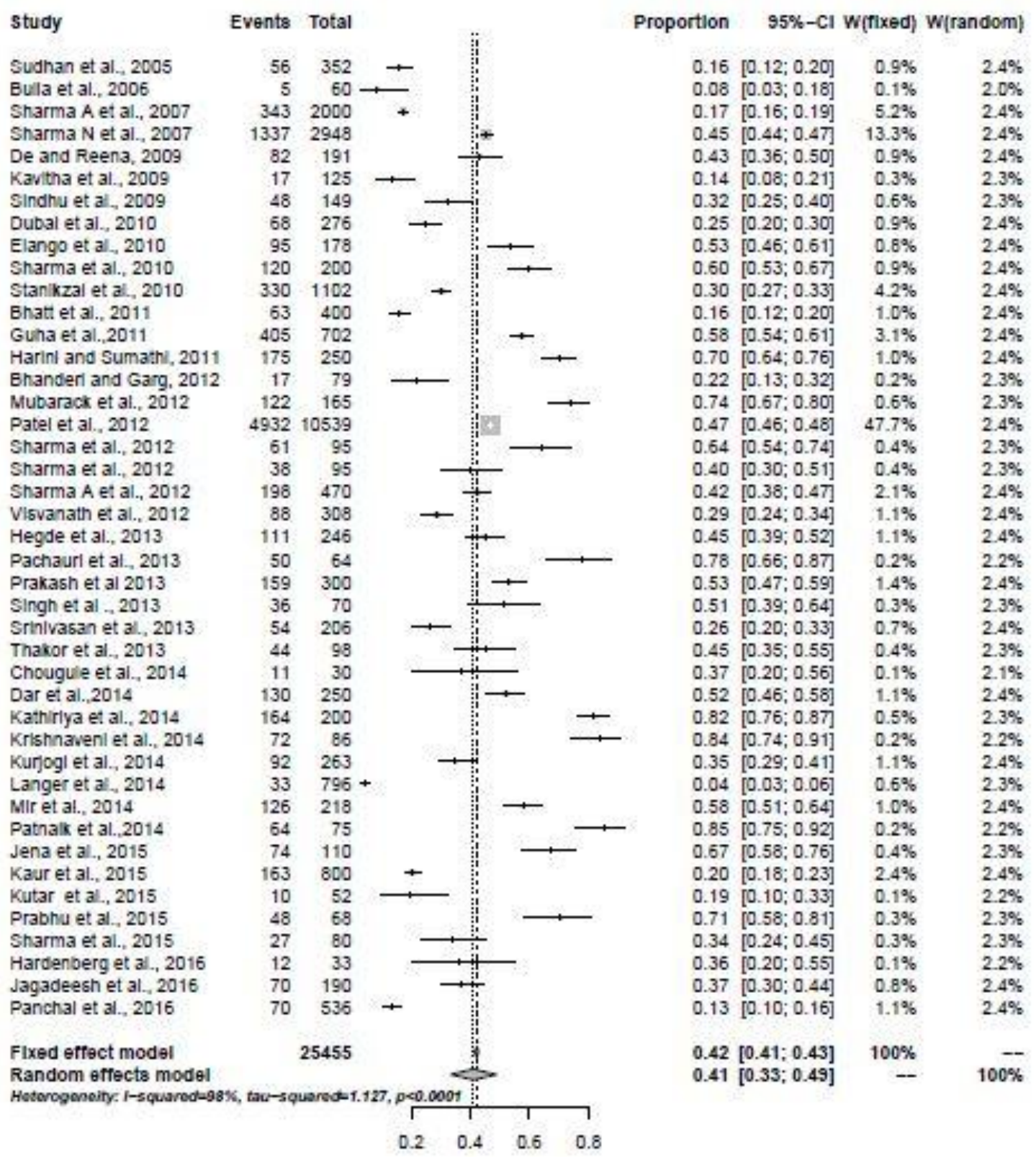


Fig.2 Forest plot showing the prevalence of clinical mastitis reported by various studies and events indicates number of mastitis affected bovines

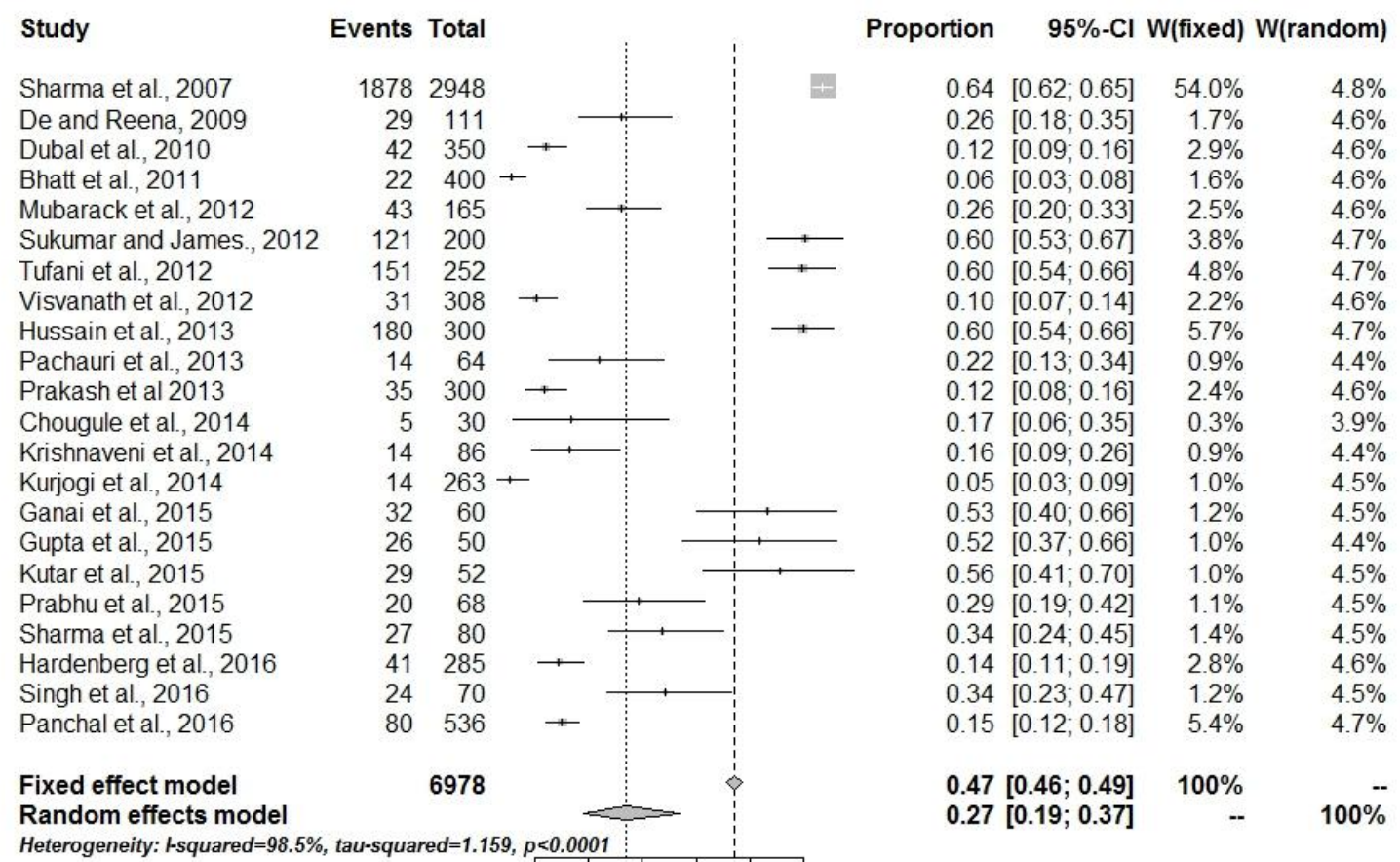


Fig.3 Forest plot showing the prevalence of Staphylococcus species mastitis reported by various studies and events indicates number of mastitis affected bovines

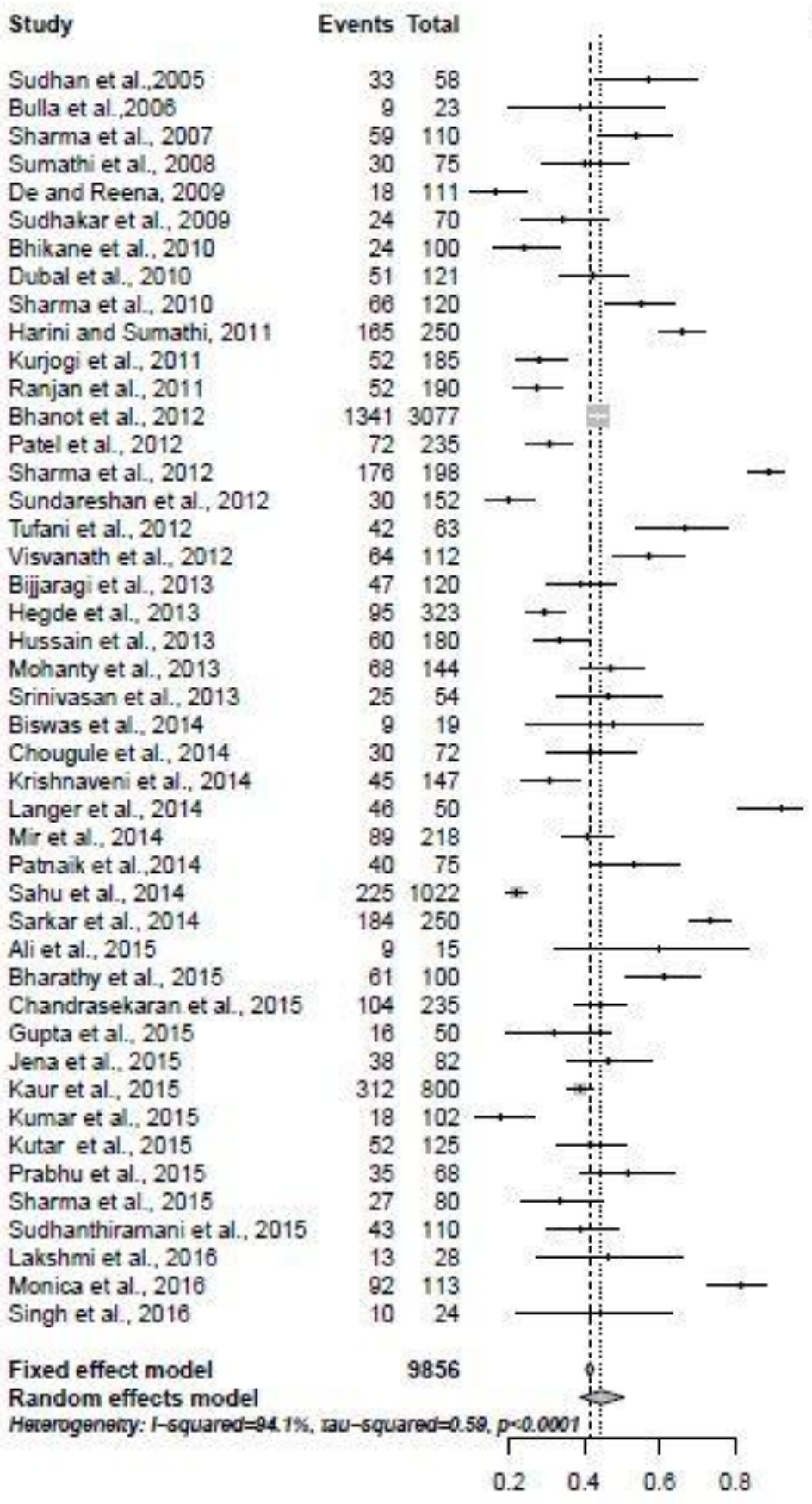

\section{Proportion $\quad 95 \%-\mathrm{Cl}$ W(fixed) W(random)}

$\begin{array}{lll}0.57[0.43 ; 0.70] & 0.7 \% & 2.2 \% \\ 0.39[0.20 ; 0.81] & 0.3 \% & 1.9 \% \\ 0.54[0.44 ; 0.63] & 1.3 \% & 2.3 \% \\ 0.40[0.29 ; 0.52] & 0.8 \% & 2.2 \% \\ 0.16[0.10 ; 0.24] & 0.7 \% & 2.2 \% \\ 0.34[0.23 ; 0.47] & 0.7 \% & 2.2 \% \\ 0.24[0.16 ; 0.34] & 0.8 \% & 2.2 \% \\ 0.42[0.33 ; 0.51] & 1.4 \% & 2.3 \% \\ 0.55[0.46 ; 0.64] & 1.4 \% & 2.3 \% \\ 0.66[0.60 ; 0.72] & 2.6 \% & 2.4 \% \\ 0.28[0.22 ; 0.35] & 1.7 \% & 2.3 \% \\ 0.27[0.21 ; 0.34] & 1.7 \% & 2.3 \% \\ 0.44[0.42 ; 0.45] & 34.8 \% & 2.4 \% \\ 0.31[0.25 ; 0.37] & 2.3 \% & 2.4 \% \\ 0.89[0.84 ; 0.93] & 0.9 \% & 2.2 \% \\ 0.20[0.14 ; 0.27] & 1.1 \% & 2.3 \% \\ 0.67[0.54 ; 0.78] & 0.6 \% & 2.2 \% \\ 0.57[0.47 ; 0.66] & 1.3 \% & 2.3 \% \\ 0.39[0.30 ; 0.48] & 1.3 \% & 2.3 \% \\ 0.29[0.24 ; 0.35] & 3.1 \% & 2.4 \% \\ 0.33[0.26 ; 0.41] & 1.8 \% & 2.3 \% \\ 0.47[0.39 ; 0.56] & 1.6 \% & 2.3 \% \\ 0.46[0.33 ; 0.60] & 0.6 \% & 2.2 \% \\ 0.47[0.24 ; 0.71] & 0.2 \% & 1.8 \% \\ 0.42[0.30 ; 0.54] & 0.8 \% & 2.2 \% \\ 0.31[0.23 ; 0.39] & 1.4 \% & 2.3 \% \\ 0.92[0.81 ; 0.98] & 0.2 \% & 1.7 \% \\ 0.41[0.34 ; 0.48] & 2.4 \% & 2.4 \% \\ 0.53[0.41 ; 0.65] & 0.9 \% & 2.2 \% \\ 0.22[0.20 ; 0.25] & 8.1 \% & 2.4 \% \\ 0.74[0.68 ; 0.79] & 2.2 \% & 2.4 \% \\ 0.80[0.32 ; 0.84] & 0.2 \% & 1.7 \% \\ 0.61[0.51 ; 0.71] & 1.1 \% & 2.3 \% \\ 0.44[0.38 ; 0.51] & 2.7 \% & 2.4 \% \\ 0.32[0.20 ; 0.47] & 0.5 \% & 2.1 \% \\ 0.46[0.35 ; 0.58] & 0.9 \% & 2.3 \% \\ 0.39[0.36 ; 0.42] & 8.7 \% & 2.4 \% \\ 0.18[0.11 ; 0.26] & 0.7 \% & 2.2 \% \\ 0.42[0.33 ; 0.51] & 1.4 \% & 2.3 \% \\ 0.51[0.39 ; 0.64] & 0.8 \% & 2.2 \% \\ 0.34[0.24 ; 0.45] & 0.8 \% & 2.2 \% \\ 0.39[0.30 ; 0.49] & 1.2 \% & 2.3 \% \\ 0.46[0.28 ; 0.86] & 0.3 \% & 2.0 \% \\ 0.81[0.73 ; 0.88] & 0.8 \% & 2.2 \% \\ 0.42[0.22 ; 0.63] & 0.3 \% & 1.9 \% \\ 0.41[0.40 ; 0.42] & 100 \% & \\ 0.45[0.39 ; 0.50] & -- & 100 \% \\ \end{array}$


Fig.4 Forest plot showing the prevalence of Streptococcus species mastitis reported by various studies and events indicates number of mastitis affected bovines

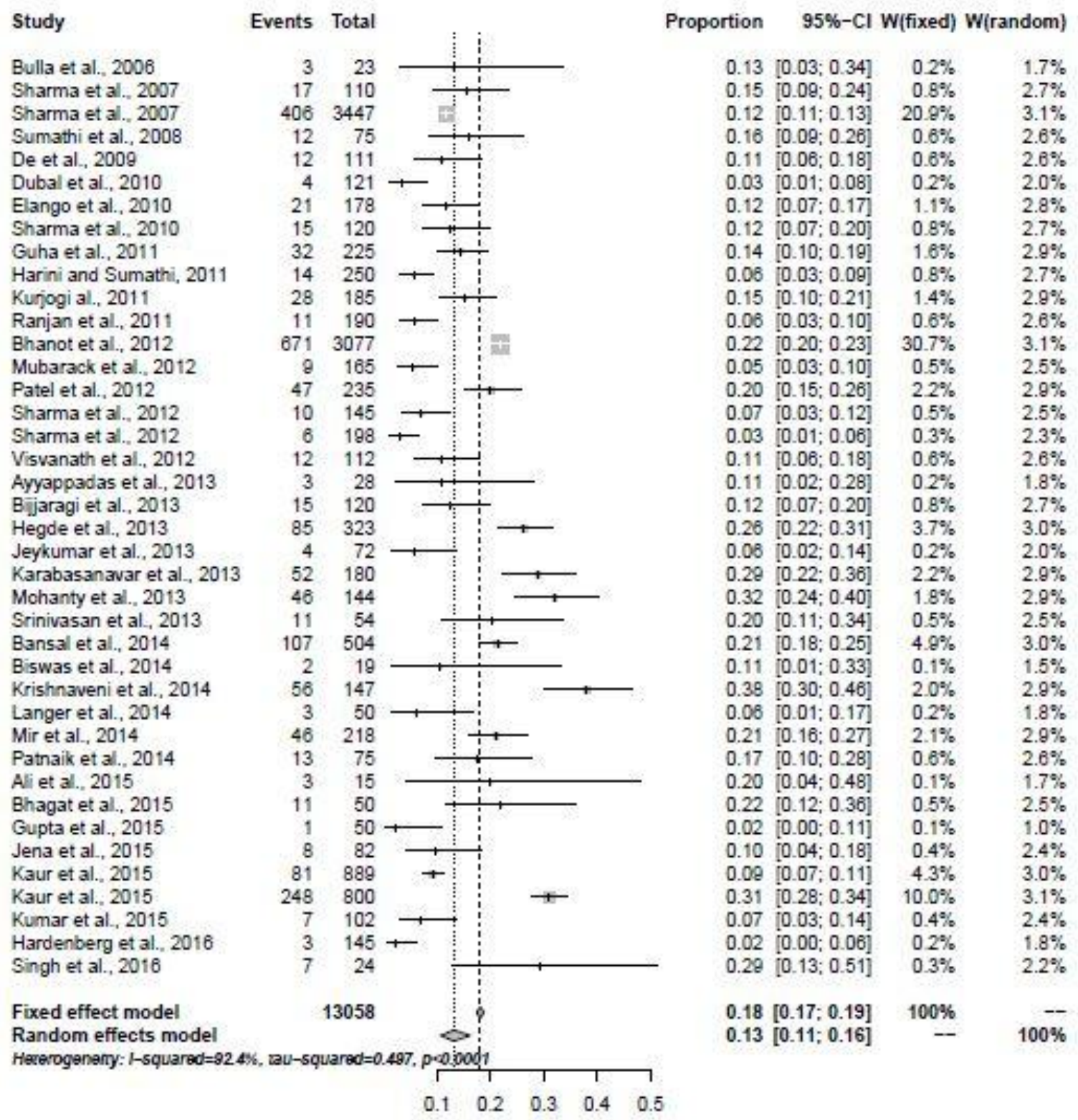


Fig.5 Forest plot showing the prevalence of Escherichia coli mastitis reported by various studies and events indicates number of mastitis affected bovines

\begin{tabular}{|c|c|c|c|c|c|c|c|}
\hline Study & Events & Total & & Proportion & $95 \%-\mathrm{Cl}$ & $W($ fixed) & W(random) \\
\hline Sudhan et al., 2005 & 1 & $58+$ & & 0.02 & [0.00;0.09] & $0.1 \%$ & $1.2 \%$ \\
\hline Sharma et al., 2007 & 14 & 110 & & 0.13 & {$[0.07 ; 0.20]$} & $0.9 \%$ & $2.7 \%$ \\
\hline Sharma et al., 2007 & 179 & 3447 & & 0.05 & {$[0.04 ; 0.06]$} & $12.1 \%$ & $3.0 \%$ \\
\hline Sumathi et al., 2008 & 15 & 75 & & 0.20 & {$[0.12 ; 0.31]$} & $0.8 \%$ & $2.7 \%$ \\
\hline Sudhakar et al., 2000 & 28 & 70 & & 0.40 & {$[0.28 ; 0.52]$} & $1.2 \%$ & $2.8 \%$ \\
\hline Bhikane et al., 2010 & 28 & 100 & & 0.28 & {$[0.19 ; 0.38]$} & $1.4 \%$ & $2.8 \%$ \\
\hline Dubal et al., 2010 & 22 & 121 & & 0.18 & {$[0.12 ; 0.26]$} & $1.3 \%$ & $2.8 \%$ \\
\hline Elango et al., 2010 & 15 & 178 & & 0.08 & {$[0.05 ; 0.14]$} & $1.0 \%$ & $2.7 \%$ \\
\hline Sharma et al., 2010 & 33 & 120 & & 0.28 & {$[0.20 ; 0.36]$} & $1.7 \%$ & $2.8 \%$ \\
\hline Guha et al., 2011 & 8 & $225+$ & & 0.04 & {$[0.02 ; 0.07]$} & $0.5 \%$ & $2.5 \%$ \\
\hline Harini and Sumathi, 2011 & 59 & 250 & & 0.24 & {$[0.18 ; 0.29]$} & $3.2 \%$ & $2.9 \%$ \\
\hline Ranjan et al., 2011 & 17 & 190 & & 0.09 & {$[0.05 ; 0.14]$} & $1.1 \%$ & $2.7 \%$ \\
\hline Bhanot et al.. 2012 & 502 & 3077 & & 0.16 & {$[0.15 ; 0.18]$} & $29.8 \%$ & $3.0 \%$ \\
\hline Hegde et al., 2012 & 48 & 323 & & 0.15 & {$[0.11 ; 0.19]$} & $2.9 \%$ & $2.9 \%$ \\
\hline Mubarack et al., 2012 & 3 & $185 \leftarrow$ & & 0.02 & {$[0.00 ; 0.05]$} & $0.2 \%$ & $2.0 \%$ \\
\hline Patel et al., 2012 & 24 & 235 & & 0.10 & {$[0.07 ; 0.15]$} & $1.5 \%$ & $2.8 \%$ \\
\hline Sadashiv and Kaliwal, 2012 & 97 & 392 & $\rightarrow$ & 0.25 & {$[0.21 ; 0.29]$} & $5.2 \%$ & $2.9 \%$ \\
\hline Sharma et al., 2012 & 6 & $198 \div$ & & 0.03 & {$[0.01 ; 0.06]$} & $0.4 \%$ & $2.4 \%$ \\
\hline Tufani et al., 2012 & 10 & 63 & & 0.16 & {$[0.08 ; 0.27]$} & $0.6 \%$ & $2.6 \%$ \\
\hline Visvanath et al., 2012 & 8 & 112 & & 0.05 & {$[0.02 ; 0.11]$} & $0.4 \%$ & $2.4 \%$ \\
\hline Ayyappadas et al., 2013 & 3 & 28 & & 0.11 & {$[0.02 ; 0.28]$} & $0.2 \%$ & $2.0 \%$ \\
\hline Bijiaragi et al., 2013 & 38 & 120 & & 0.32 & {$[0.23 ; 0.41]$} & $1.8 \%$ & $2.8 \%$ \\
\hline Hegde et al., 2013 & 48 & 323 & & 0.15 & {$[0.11 ; 0.19]$} & $2.9 \%$ & $2.9 \%$ \\
\hline Mohanty et al., 2013 & 30 & 144 & & 0.21 & {$[0.15 ; 0.28]$} & $1.7 \%$ & $2.8 \%$ \\
\hline Srinivasan et al., 2013 & 6 & 54 & & 0.11 & {$[0.04 ; 0.23]$} & $0.4 \%$ & $2.4 \%$ \\
\hline Bansal et al., 2014 & 36 & 504 & & 0.07 & {$[0.05 ; 0.10]$} & $2.4 \%$ & $2.9 \%$ \\
\hline Biswas et al., 2014 & 5 & 19 & & 0.26 & {$[0.09 ; 0.51]$} & $0.3 \%$ & $2.2 \%$ \\
\hline Krishnaveni et al., 2014 & 23 & 147 & & 0.16 & {$[0.10 ; 0.23]$} & $1.4 \%$ & $2.8 \%$ \\
\hline Langer et al., 2014 & 1 & 50 & & 0.02 & {$[0.00 ; 0.11]$} & $0.1 \%$ & $1.2 \%$ \\
\hline Patnaik et al., 2014 & 11 & 75 & & 0.15 & {$[0.08 ; 0.25]$} & $0.7 \%$ & $2.8 \%$ \\
\hline Ali et al., 2015 & 2 & 15 & & 0.13 & {$[0.02 ; 0.40]$} & $0.1 \%$ & $1.7 \%$ \\
\hline Chandrasekaran et al., 2015 & 119 & 235 & $\longrightarrow$ & 0.51 & {$[0.44 ; 0.57]$} & $4.2 \%$ & $2.8 \%$ \\
\hline Gupta et al., 2015 & 20 & 50 & & 0.40 & {$[0.26 ; 0.55]$} & $0.8 \%$ & $2.7 \%$ \\
\hline Jena et al., 2015 & 5 & 82 & & 0.08 & {$[0.02 ; 0.14]$} & $0.3 \%$ & $2.3 \%$ \\
\hline Kaur et al., 2015 & 221 & 889 & $\mp$ & 0.25 & {$[0.22 ; 0.28]$} & $11.8 \%$ & $3.0 \%$ \\
\hline Kaur et al., 2015 & 40 & 800 & & 0.05 & {$[0.04 ; 0.07]$} & $2.7 \%$ & $2.9 \%$ \\
\hline Kumar et al., 2015 & 8 & 102 & & 0.08 & {$[0.03 ; 0.15]$} & $0.5 \%$ & $2.5 \%$ \\
\hline Lakshmi et al., 2016 & 19 & 145 & & 0.13 & {$[0.08 ; 0.20]$} & $1.2 \%$ & $2.8 \%$ \\
\hline Singh et al., 2016 & 4 & 24 & & 0.17 & {$[0.05 ; 0.37]$} & $0.2 \%$ & $2.1 \%$ \\
\hline \multirow{4}{*}{$\begin{array}{l}\text { Fixed effect model } \\
\text { Random effects model } \\
\text { Hererogeneny: } \mid \text {-squared }=95.3\end{array}$} & & 13315 & & 0.16 & {$[0.15 ; 0.16]$} & $100 \%$ & - \\
\hline & & & & 0.14 & {$[0.11 ; 0.17]$} & - & $100 \%$ \\
\hline & & & . & & & & \\
\hline & & & $0.2 \quad 0.3$ & & & & \\
\hline
\end{tabular}

However, the SCM was caused by many pathogens, without any clinical signs and unobservable nature of the infection, which is leading to major economic loss to the dairy farmers in India. The period-wise prevalence of CM was decreasing during 2011-16 when compared to 2005-11, which might be due to the awareness among the dairy farmers about the mastitis. The prevalence of clinical mastitis in Badulla district in Sri Lanka was $3.8 \%$ (Samarakoon et al., 2014), which was low when compared to the present study. Many studies on subclinical and clinical mastitis have been reported from North and South zones which may be due to the presence of more cases of mastitis and also more population of cattle and buffaloes in these regions. The pooled prevalence of Staphylococcus sp. was more (45\%) when compared to Streptococcus sp. (13\%) and E. coli (14\%), which might be due to mastitis caused by both coagulase positive and negative Staphylococcus species. Further, more number of species from Staphylococcus group causing mastitis than other species and it is the predominant mastitis pathogen in India. The finding of Staphylococcus sp., to be predominant bacteria involved in mastitis milk concurred with previous report (Bhanot et al., 2012). In a study in 
North West of Iran, the Staphylococcal species associated with mastitis was found to be $71.5 \%$ (Hosseinzadeh and Saei, 2014) and was higher than the present study. Over the years, the pooled prevalence estimate revealed increase in Staphylococcus species mastitis when compared to other two major mastitis pathogens. This might be due to detection and identification of more number of Staphylococcus species by advanced molecular methods by species specific PCR, multiplex PCR and two tube PCR as well as by conventional methods.

Zone wise analysis revealed higher prevalence of Staphylococcus and Streptococcus species from North and Central zones and for E. coli was high in East and South zones. The number of prevalence studies on mastitis was increasing in recent years and might be due to advanced diagnostic methods and also due to the awareness among the dairy farmers about the quality of milk which will help them in getting more price for the milk produced.

The prevalence estimate in the present study should be viewed with certain limitations, as it does not provide the estimate for the association of disease incidence with risk factors. Further, there are many factors which causes variation between the studies are breed, lactation number, milk yield, management practices, climatic conditions, geographical conditions and period of study may affect the prevalence of SCM and CM in dairy cattle. In order to compare the results between different studies and diagnostic tests, a common test for SCM and CM were considered as diagnostic criteria, in case of major mastitis pathogens, isolation of organisms is considered as diagnostic criteria.

In conclusion, the present study estimated the pooled prevalence of subclinical, clinical mastitis and major mastitis pathogens in dairy cattle in India using the random effects model. There is high prevalence of SCM than CM indicating the importance of SCM and need for scientific management methods to be adopted to minimize the incidence of SCM in dairy cows in India. The high prevalence of subclinical mastitis in dairy cattle may cause low milk yield over the years and lead to greater economic loss to the dairy farmers.
Staphylococcus species is more prevalent in mastitis than other pathogens in India. Hence, the study advocates, to overcome the occurrence of mastitis, there is need for scientific management practices and timely therapeutic interventions by field veterinarians, so as to improve the productivity of dairy animals in India. Further, more studies were reported from North and South zones, however, to assess the overall prevalence levels of mastitis in India and across the zones, there is a need for more studies on mastitis prevalence from Central and East zones of India.

\section{Conflict of Interest}

The authors declare no conflict of interest.

\section{Acknowledgement}

The authors thank the Deputy Director General (Animal Science), Indian Council of Agricultural Research, New Delhi for providing necessary support to conduct this study.

\section{References}

Ali, Z., Dimri, U. and Jhambh, R. 2015. Prevalence and antibiogram of bacterial pathogens from subclinical mastitis in buffaloes. Buff. Bull., 34: 41-44.

Ayyappadas, M.P. and Renugadevi. 2013. Study on the prevalence, incidence, drug sensitivity and extra chromosomal impact on bovine mastitis pathogens. IOSR J. Agri. Vet. Sci., 2: 60-62.

Bajjaragi, S.C., Ahmed, R.N. and Lilaram. 2013. A preliminary study on prevalence of bovine mastitis in Dharwad Region (North Karnataka), India. Intl. J. Scientific Res., 2: 529-30.

Bangar, Y.C., Singh, B., Dohare, A.K. and Verma, M.R. 2015. A systematic review and meta-analysis of prevalence of subclinical mastitis in dairy cows in India. Trop. Anim. Health Prod., 47: 291-297.

Bansal, B.K. and Gupta, D.K. 2009. Economic analysis of bovine mastitis in India and Punjab - a review. Indian J. Dairy Sci., 62: 337-345. 
Bhagat, A.G., Kher, H.N., Dadawala, A.I., Chauhan, H.C., Chandel, B.S. and Shah, N.M. 2015. Isolation, Identification and antibiogram of Streptococcus agalactiae isolation from the bovine mastitis. The Indian Vet J., 92: 27-29.

Bhanderi, B.M. and Garg, M.R. 2012. A study on reducing the incidence of subclinical mastitis in dairy cows by feeding a vitamins and minerals based strategic feed supplement. Indian $J$. Dairy Sci., 65: 388-392.

Bhanot, V., Chaudhri, S.S., Bisla, R.S. and Singh, H. 2012. Retrospective study on prevalence and antibiogram of mastitis in cows and buffaloes of eastern Haryana. Indian J. Anim. Res., 46: 160 163.

Bharathy, S., Gunaseelan, L., Porteen, K. and Bojiraj, M. 2015. Prevalence of Staphylococcus aureus in raw milk, can it be a potential public health threat. Intl. J. Adv. Res., 3: 801-806.

Bhatt, V.D., Patel, M.S., Joshi, C.G. and Kunjadia, A. 2011. Identification and antibiogram of microbes associated with bovine mastitis. Anim. Biotech., 22: 163-169.

Bhikane, A.U., Awandkar, S.P., Hase, P.B., Syed, A.M., Ghoke, S.S. and Awaz, K.B. 2010. Prevalence, etiology and antibiogram of subclinical mastitis in crossbred cows. Vet. Practitioner, 11: 122-123.

Biswas, S., Mukherjee, R., Mahto, R.P, De, U.K., Chakravarti, S., Bera, A.K. and Deb, S.M. 2014. Antibacterial Sensitivity and Resistance Pattern of Yak Intramammary Infection from Arunachal Pradesh, India. Asian $J$. Anim. Vet. Adv., 9: 683-689.

Bulla, T.R., Rana, Y.S., Sharma, A. and Beniwal, B.S. 2006. Prevalence of subclinical mastitis in Murrah buffaloes. Haryana Vet., 45: 53-56.

Chandrasekaran, D., Nambi, A.P.,
Thirunavukkarasu, P.S., Venkatesh, P., Thirumuragaan, S. and Vairamuthu, S. 2015. Incidence of resistant mastitis in dairy cows in Tamil Nadu, India. $J$. Appl. Natl. Sci., 7: 304-308.

Chougule, M.N., Gandge, R.S., Bannalikar, A.S., Majee, S.B. and Pharande, R.R. 2014. Characterization of Staphylococcus aureus associated with bovine mastitis. Indian J. Dairy Sci., 67: 493-497.

Cynthia, M.K. 2005. The Merck Veterinary Manual. Whitehouse station, Merck and Company Incl., New Jersey, USA.

Dar, K.H., Ansari, D.S.H., Tantary, H.A., Baba, M.A. and Naikoo, M.D. 2014. Study on subclinical mastitis in dairy cows of Jammu and Kashmir. Intl. J. Vet. Sci., 3: 95-99.

De, U.K. and Reena, M. 2009. Prevalence of mastitis in crossbred cows. The Indian Vet. J., 86: 858-859.

Dubal, Z.B., Rahman, H., Pal, P., Kumar, A. and Pradhan, K. 2010. Characterization and antimicrobial sensitivity of pathogens isolated from bovine mastitis with special reference to Escherichia coli and Staphylococcus spp. Indian J. Anim. Sci., 80: 1163-1167.

Elango, A., Doraisamy, K.A., Rajarajan, G. and Kumaresan G. 2010. Bacteriology of sub clinical mastitis and antibiogram of isolates recovered from cross bred cows. Indian J. Anim. Res., 44: 280284.

Ganai, A.W., Kotwal, S.K., Malik, M.A., Sharma, H.K., Wani, N. and Jeelani, R. 2015. Prevalence of Staphylococcus aureus and methicillin resistant Staphylococcus aureus (MRSA) in clinical setting and dairy farm environment of Jammu. J. Anim. Res., 5: 539-545.

Guha, A. and Gera, S. 2011. Etio-prevalence of sub clinical mastitis in Holstein $\mathrm{X}$ Haryana crossbred cattle. Exploratory 
Anim. Medl. Res., 1: 75-78.

Gupta, N., Faridi, F., Maherchandani, S. and Kashyap, S.K. 2015. Detection and genetic characterization of major pathogens isolated from bovine mastitis in Rajasthan. Indian J. Vet. Sci. Biotech., 11: 1-6.

Hardenberg, F. 2016. Clinical and sub-clinical mastitis in dairy cattle and buffaloes in Bihar, India. Swedish University of Agricultural Sciences, Uppsala, Sweden.

Harini, H. and Sumathi, B.R. 2011. Screening of bovine milk samples for subclinical mastitis and antibiogram of bacterial isolates. Vet World. 4: 35.

Hegde, R., Isloor, S., Prabhu, K.N., Shome, B.R., Rathnamma, D., Suryanarayana, V.V.S., Yathiraj, S., Prasad, C.R., Krishnaveni, N., Sundareshan, S., Akhila, D.S., Gomes, A.R. and Hedge, N.R. 2013. Incidence of sub-clinical mastitis and prevalence of major mastitis pathogens in organized farms and unorganized sectors. Indian $J$. Microbiol. 53: 315-320.

Higgins, J.P.T., Lane, P.W., Anagnostelis, B., Anzures-Cabrera, J., Baker, N.F., Cappelleri, J.C., Haughie, S., Hollis, S., Lewis, S.C., Moneuse, P. and Whitehead, A. 2013. A tool to assess the quality of a metaanalysis. Res. Syn. Methods, 4: 351366.

Hogeveen, H., Huijps, K. and Lam, T.J.G.M. 2011. Economic aspects of mastitis: New developments, New Zealand Vet. J., 59: 16-23.

Hosseinzadeh, S. and Saei, H.D. 2014. Staphylococcal species associated with bovine mastitis in the North West of Iran: Emerging of coagulase-negative staphylococci. Intl. J. Vet. Sci. Med., 2: 27-34.

Hussain, A., Ahmed, M.D., Mushtaq, M.H., Khan, M.S., Khan, M.A., Nisar, M.,
Sabi, N. and Khan, A.K. 2013. Antibiogram analysis of Staphylococcus aureus isolated from mastitic milk samples of Buffaloes in District Bhimber Azad Kashmir. Buff Bull., 32: 1021-1028.

Islam, M.A., Islam, M.Z., Islam, M.A., Rahman, M.S. and Islam, M.T. 2011. Prevalence of subclinical mastitis in dairy cows in selected areas of Bangladesh. Bangladesh J. Vet. Med., 9: 73-78.

Jagadeesh, D.S., Puttamallappa, R.K., Gowda, H. and Keregallokoppalu, L.M. 2016. Prevalence of subclinical mastitis in cattle and effect on milk quality. $A d v$. Anim. Vet. Sci., 4: 237-240.

Jena, B., Pagrut, N.K., Sahoo, A. and Ahmed, A. 2015. Subclinical bovine mastitis in rural, peri-urban and suburban regions of Jaipur district of Rajasthan, India. $J$. Anim. Res., 5: 175-182.

Jeykumar, M., Vinodkumar, G., Basher, B.P. and Krovvidi, S. 2013. Antibiogram of mastitis pathogens in the milk of crossbred in cows in Namakkal district, Tamil Nadu. Vet World. 6: 354-356.

Joshi, S. and Gokhale, S. 2006. Status of mastitis as an emerging disease in improved and peri urban dairy farms in India. Annals NY Acad. Sci., 1081: 7483.

Karabasanavar, N.S. and Singh, S.P. 2013. Isolation and antibiogram of coagulase negative Staphylococci from bovine mastitis milk. J. Food borne Zoonotic Dis., 1: 21-23.

Kathiriya, J.B., Kabariya, B.B., Saradava, D.A. and Sanepara, D.P. 2014. Prevalence of subclinical mastitis in dairy cows in Rajkot district of Gujarat. Intl. J. Sci. Nat., 5: 433-436.

Kaur, A., Singh, S.G. and Singh, V. 2015. Seasonal prevalence and antibiogram profile of bacterial isolates from bovine mastitis. J. Anim. Res., 5: 623-629. 
Kaur, M., Ramneek, Bansal, B.K., Mukhopadhyay, C.S. and Arora, J.S. 2015. Status of sub-clinical mastitis and associated risk factors in Indian water buffaloes in Doaba region of Punjab, India. Indian J. Dairy Sci., 68: 483-487.

Kavitha, K.L., Rajesh, K., Suresh, K., Satheesh, K. and Syama S.N. 2009. Buffalo mastitis- risk factors. Buff Bull., 28: 134-137.

Koricheva, J., Gurevitch, J. and Mengersen, K. 2013. Handbook of meta-analysis in ecology and evolution. Princeton University Press, New Jersey, USA.

Krishnaveni, N., Isloor, S.K., Hegde, R., Suryanarayana, V.V.S., Rathnma, D., Veeregowda, B.M., Nagaraja, C.S. and Sundareshan, S.2014. Rapid detection of virulence associated genes in Streptococcal isolates from bovine mastitis. African J. Microbiol. Res., 8: 2245-2254.

Kumar, A., Haque, S., Singh, K.K. and Roy, B.K. 2015. Bacteriology and antibiogram of bovine mastitis in Ranchi and its vicinity. Intl. J. Sci. Environ. Tech., 4: 1066-1072.

Kurjogi, M.M. and Basappa, B.K. 2014. Epidemiology of bovine mastitis in cows of Dharwad district. Intl Scholarly Res. Notices ID968076: 1-9.

Kutar, K., Verma, A.K., Sharma, B., Kumar, A. and Yadav, S.K. 2015. Analysis of mec A gene and antibiotic resistance in Staphylococcus aureus isolates from bovine mastitis. Indian J. Comp. Microbiol. Immunol. Infect. Dis., 36: 22-27.

Langer, A., Sharma, S., Sharma, N.K. and Nauriyal, D.S. 2014. Comparative efficacy of different mastitis markers for diagnosis of subclinical mastitis in cows. Intl J Appl Sci Biotech. 2: 121125.

Laxmi, R. and Jayavardhanan, K.K. 2016. Isolation and identification of major causing bacteria from bovine mastitis. Intl J Appl Pure Sci Agri. 2: 45-48.

Mir, A.Q., Bansal, B.K. and Gupta, D.K. 2014. Sub-clinical mastitis in machine milked dairy farms in Punjab: prevalence, distribution of bacteria and current antibiogram. Vet World. 7: 291294.

Mohanty, N.N., Das, P., Pany, S.S., Sarangi, L.N., Ranabijuli, S. and Panda, H.K. 2013. Isolation and antibiogram of Staphylococcus, Streptococcus and Escherichia coli isolates from clinical and subclinical cases of bovine mastitis. Vet World. 6: 739-743.

Monica, S.G., Gunaseelan. L., Sekar, M. and Begum, S. 2016. Study on antibiotics resistance of Staphylococcus aureus isolated from bovine raw milk. Indian Vet. J., 93: 37-40.

Mubarack, H.M., Doss, A. and Vijayasanthi, M. 2012. Study on prevalence of bovine mastitis on dairy cows in and around Coimbatore district, Tamil Nadu, India. Indian J. Drug Dis., 1: 35-38.

Pachauri, S., Varshney, P., Dash, S.K. and Gupta, M.K. 2013. Involvement of fungal species in bovine mastitis in and around Mathura, India. Vet. World, 6: 393-395.

Panchal, I., Sawhney, I.K. and Dang, A.K. 2016. Relation between electrical conductivity, dielectric constant, somatic cell count and some other milk quality parameters in diagnosis of subclinical mastitis in Murrah buffaloes. Indian J. Dairy Sci., 69: 267-271.

Patel, J.V., Bhingaradia, B.V., Patel, B., Patel, S.B., Patel, P.B. and Vahora, S.P. 2012. Study on prevalence of mastitis and antibiotic sensitivity of bacterial isolates recovered from crossbred cows of Anand district of Gujarat. Indian J. Dairy Sci., 65: 467-471.

Patnaik, S., Prasad, A. and Ganguly, S. 2014. Biochemical characterization and 
antibiogram of staphylococcal microorganisms associated with subclinical mastitis in lactating crossbred cows. Anim. Sci. Reporter. 8: 123-129.

Prabhu, K.N., Ruban, W.S., Kumar, G.S.N., Sharada, R. and Padalkar, R.D. 2015. Sub-clinical mastitis in buffaloes: prevalence, isolation and antimicrobial resistance of Staphylococcus aureus. Buff Bull., 34: 215-222.

Prakash, V., Bano, S., Yadav, M.P.S., Singh, R.B. and Singh, S.P. 2013. Various factors responsible for subclinical and clinical mastitis and pharmacotherapeutic role of trisodium citrate. The Asian J. Anim. Sci., 8: 3739.

Rahman, M.M., Islam, M.R., Uddin, M.B. and Aktaruzzaman, M. 2010. Prevalence of subclinical mastitis in dairy cow reared in sylhet district of Bangladesh. Intl. J. Biol. Res., 1: 23-28.

Ranjan, R., Gupta, M.K. and Singh, K.K. 2011. Study of bovine mastitis in different climatic conditions in Jharkhand, India. Vet. World, 4: 205208.

Sadashiv, S.O. and Kaliwal, B.B. 2012. Screening and antibiotic resistance of Escherichia coli isolated from bovine mastitis in the region of North Karnataka, India. Indo-American $J$. Pharmaceutical Res., 5: 1309-1316.

Sahu, B.D., Mukherjee, R., Kumar, A., Kumar, A. and Sahu, J. 2014. Prevalence of coagulase gene positive Staphylococcus aureus bovine mastitis in three distinct geoclimatic regions of India. Buff Bull., 33: 208-214.

Samarakoon, S.J.M.R.R., Dangolla, A. and Karunarathne, W.M.S.K. 2014. Some findings of mastitis control programme in Badulla district in Sri Lanka in 2012. SLVet J. 61: 11-13.

Sarkar, P., Mohanto, D., Sachinandan, De. and Debnath, C. 2014. Staphylococcus aureus in dairy animals and farm workers in a closed herd in Karnal, North India: assessment of prevalence rate and CoA variation. Intl J Innovative Res Sci Eng Tech. 3: 10962-10971.

Sarker, S.C., Parvin, M.S., Rahman, A.K. and Islam, M.T. 2013. Prevalence and risk factors of subclinical mastitis in lactating dairy cows in north and south regions of Bangladesh. Trop Anim Health Prod. 45: 1171-1176.

Sharma, A. and Sindhu, N. 2007. Occurrence of clinical and sub-clinical mastitis in buffaloes in the state of Haryana, India. Italian J Anim Sci. 6: 965-967.

Sharma, A., Singh, R., Beigh, S.A. and Bhardwaj, R.K. 2012. Prevalence of sub clinical mastitis in cross breed cattle from Jammu region. Vet Practitioner. 13: 356-357.

Sharma, D.K., Jallewar, P.K. and Sharma, K.K. 2010. Antibiogram of bacteria isolated from bovine sub-clinical mastitis. Indian Vet J. 87: 407.

Sharma, L., Verma, A.K., Kumar, A., Rahat, A. and Nigam, R. 2015. Incidence and pattern of antibiotic resistance of Staphylococcus aureus isolated from clinical and subclinical mastitis in cattle and buffaloes. Asian J Anim Sci. 9: 100-109.

Sharma, N., Maiti, S.K. and Sharma, K.K. 2007. Prevalence, etiology and antibiogram of microorganisms associated with sub clinical mastitis in buffaloes in Durg, Chhattisgarh state (India). Intl J Dairy Sci. 2: 145-151.

Sharma, P.A., Chhabra, R. and Sindhu, N. 2012. Prevalence of subclinical mastitis in cows: Its etiology and antibiogram. Indian J Anim Res. 46: 348-353.

Sindhu, N., Sharma, A., Nehra, V. and Jain, V.K. 2009. Prevalence of sub clinical mastitis in cows: its etiology and antibiogram. Haryana Vet., 48: 85-87. 
Singh, A., Doley, P. and Neeraj. 2013. Prevalence of subclinical mastitis in cow herd on Allahabad region. Indian J. Biotech. Pharmaceutical Res., 1: 41-43.

Singh, N., Singh, P. and Patel, R.K. 2016. Isolation and Identification of bacterial organisms from mastitic milk. $J$ Livestock Sci. 7: 46-48.

Srinivasan, P., Jagadeswaran, D., Manoharan, R., Giri, T., Balasubramanian, G.A. and Balachandran, P. 2013. Prevalence and etiology of sub-clinical mastitis among buffaloes (Bubalus bubalus) in Namakkal, India. Pak J Biological Sci. 16: 1776-1780.

Stanikzai, P.M., Yathiraj, S., Shridhar, N.B., Ansar, K.C. and Bhat, M.N. 2010. Prevalence of subclinical mastitis in dairy cattle in and around Bangalore. International Buffalo Conference. $1-4^{\text {th }}$ February, 2010 at NASC, New Delhi.

Sudhakar, P.A., Khode, N.V., Sardar, V.M. and Mendhe, M.S. 2009. Prevalence and current antibiogram trend of mastitis agents in Udgir and its vicinity, Maharashtra State, India. Indian J Dairy Sci. 4: 117-122.

Sudhan, N.A., Singh, R., Singh, M. and Soodan, J.S. 2005. Studies on prevalence, etiology and diagnosis of sub clinical mastitis among crossed cows. Indian J Anim Res. 39: 127-130.

Sudhanthiramani, S., Swetha, C.S. and Bharathy, S. 2015. Prevalence of antibiotic resistant Staphylococcus aureus from raw milk samples collected from the local vendors in the region of Tirupathi, India. Vet World. 8: 478-481.
Sukumar, K. and James, P.C. 2012. Incidence of fungal mastitis in cattle. Tamilnadu $J$ Vet Anim Sci. 8: 356-359.

Sumathi, B.R., Veeregowda, B.M. and Amitha, R.G. 2008. Prevalence and antibiogram profile of bacterial isolates from clinical bovine mastitis. Vet World. 1: 237-238.

Sundareshan, S., Isloor, S., Hari Babu, Y., Awati, B., Deshpande, P.V., Deore, S., Hegde, R., Nithin, K.P., Sunagar, R., Babra, C., Tiwari, J.G., Mukkur, T.K. and Hedge, N.R. 2012. Development of multiplex PCR for detection of coagulase negative Staphylococcus-The emerging mastitis pathogens in bovines in India and their antimicrobial resistance. Indian Association of Veterinary Microbiologists, Immunologists and Specialists in Infectious Diseases, 6-8 ${ }^{\text {th }}$ September, 2012, Bangalore, India, 102.

Thakor, D. and Patel, D. 2013. Prevalence and antibiogram pattern of subclinical mastitis in crossbred cows. Natural Remedies Private Limited.

Tufani, N.A., Makhdoom, D.M. and Hafiz, A. 2012. Epidemiology and therapeutic management of bovine mastitis. Indian J. Anim. Res., 46: 148-151.

Visvanath, K., Shoba, K., Dorairajan, N., Srithar, A. and Chandran, N.D.J. 2012. Clinical and sub-clinical bovine mastitis in Chelliyaeeplayam, Namakkal district. Indian Association of Veterinary Microbiologists, Immunologists and Specialists in Infectious Diseases $6-8^{\text {th }}$ September, 2012, Bangalore, India, 255.

\section{How to cite this article:}

Krishnamoorthy, P., K.P. Suresh, S. Saha, G. Govindaraj, B.R. Shome and Parimal Roy. 2017. Meta-analysis of Prevalence of Subclinical and Clinical Mastitis, Major Mastitis Pathogens in Dairy Cattle in India. Int.J.Curr.Microbiol.App.Sci. 6(3): 1214-1234. doi: https://doi.org/10.20546/ijcmas.2017.603.141 